\title{
Пермиловская А.Б. Русский Север - специфический код культурной памяти
}

Аннотация: Предметом исследования являются особенности формирования уникального в ментальном и социокультурном отношении региона - Русского Севера. Объект исследования: концепт «Русский Север» как специфический код культурной памяти в России. Эмпирической базой работы послужил материал 34 архитектурно-этнографических экспедиций, в которых были обследованы 368 поселений Архангельской, Вологодской областей, Карелии. В качестве источника исследований использованы архивные материалы и музейные коллекции Архангельска, Петрозаводска, Вологды, Мурманска, Нижнего Новгорода, Омска, Москвы, Санкт-Петербурга. Статья основывается на использовании комплекса методов: системного, историко-типологического, культурно-исторического, социокультурного, этнокультурологического, семиотического искусствоведческого. В соответствии с поставленными целями рассматривается структура понятия «Русский» (Европейский) Север», его территориальные и этнокультурные границы в контексте исторического формирования и заселения северных земель русским этносом. Рассматривается северная ойкумена, в которой сбормировался особый тип ментальности, опорой которого было православие, образовалась целая монашеская область - «Северная (Русская) Фиваида». Отмечается, что основой культурного кода «Русский Север» были отсутствие крепостного права, монголотатарского ига, распространение старообрядчества, длительное сохранение традиций земского самоуправления. Указано на формирование особого субэтноса - поморов, которые выработали бесценный опыт выживания и хозяйственной деятельности в экстремальных условиях Арктики, свободной торговля с европейскими странами, наличие пиджин. Это позволяет высказать новое научное предположение: жители Русского Севера были, скорее, гражданами мира, чем подневольными подданными Российской империи. Результат исследования и вывод данной статьи позволяет утверждать, что в течение последних двух столетий Русский Север стал устойчивым словосочетанием, характеризующим компоненту российского менталитета, понятие, отражающее важные для отечественной культуры смыслы. Русский Север сыграл выдающуюся роль в становлении национального самосознания и занимает одно из важнейших мест на культурной карте России.

Ключевъе слова: Русский Север, Россия, культурный код, менталитет, православие, поморы, люди мира, пиджин, старообрядчество, Русская Фиваида.

Review: The research subject is the features of the formation of a unique mental and socio-cultural concept of the Russian North. The research object is the Russian North concept as a specific code of the Russian cultural memory. The article is based on the use of a combination of methods: system, historical typological, cultural-historical, social-cultural, ethnic-cultural analysis, semiotics and art criticism. The empirical base of the research is 34 architectural-ethnographic expeditions during which 368 settlements of the Arkhangelsk, Vologda regions and Karelia were studied. The source of research includes archival materials and museum collections of Arkhangelsk, Petrozavodsk, Vologda, Nizhny Novgorod, Omsk, Moscow and St. Petersburg. In accordance with the objectives, "the Russian" (European) North" concept structure is considered as well as its territorial, ethno-cultural boundaries in the context of the historical formation and settlement of the lands north of the Russian ethnos. The research also covers the northern ecumene where a special type of mentality was developed based on Orthodox religion and the monastic area, "the Northern (Russian) Thebaid" was created. According to the author, the basis of the "Russian North" cultural code was the absence of serfdom and the Mongol-Tatar yoke, the spread of the Old Belief and long-term preservation of traditions of zemsky self-government. The study indicates the formation of a special ethnic group called "Pomors". They have developed invaluable experience of survival and economic activities in the Arctic extreme conditions, free trade with the European countries and the presence of pidgin. This allows to make the following assumption: the Russian North people were more citizens of the world, than servile citizens of the Russian Empire. The result of the study and conclusion is that in the last two centuries the Russian North has become a stable word combination characterizing the 
component of the Russian mentality and the concept reflecting the ideas that are important for the Russian culture. The Russian North has played an outstanding role in the becoming of the national consciousness and takes one of the major places on the Russian cultural map.

Keywords: Ppidgin, Russian North, Russia, cultural code, mentality, Orthodoxy, Pomors, people of the world, Old Belief, Russian (Northern) Thebaid.

Исследование выполнено при финансовой поддержке ФАНО России в рамках темъ № 0410-2014-оО27 «Состояние и использование биоресурсов в контексте оптимизации природопользования, обусловленного историко-культурными и этносоциальными процессами на Европейском Севере и в Арктике».

$\mathrm{C}$ труктура понятия «Русский Север» как определенной территории и историко-культурной общности сформировалась в результате русской колонизации из Новгородских и Ростово-Суздальских земель и ассимиляции коренного финно-угорского населения. «Русский Север» - это термин, обладающий высокой степенью универсальности и теоретичности для обозначения особого, символического русского пространства, обозначающего, кроме прочего, и государственные границы России. В связи с этим понятие «Русский Север» сохраняет свою актуальность с XIX - начала XX в., когда в науке и искусстве осуществляется его «открытие», до наших дней. В кругу концептов отечественной истории и культуры «Русский Север» - это устойчивое словосочетание для носителя российского менталитета и эта территория занимает одно из важнейших мест на культурной карте России [1,2,3].

Обширную территорию Европейского Севера обычно называют Русским Севером, или просто Севером. Этот край формировался в тесном контакте с остальными европейскими территориями, поэтому сущность и значение всего региона правильнее отражает понятие «Европейский Север», хотя оба названия часто употребляются как синонимы. Исследователи по-разному относятся к границам этого региона, особенно его южной части. Ряд исследователей считает, что не следует ограничивать понятие «Русский Север» пределами бывшей Архангельской, Вологодской и Олонецкой губерний (иногда даже одной), а распространить его значительно шире, в первую очередь на территории, которые, с исторической точки зрения, не могут быть отделены от севернорусского региона. Это северо-восток бывшей Санкт-Петербургской губернии, а также бывшая Новгородская и Тверская, северная часть Костромской губернии [4, C.4].
В настоящее время под Русским Севером подразумевают территорию от междуречья Волги и Сухоны до Белого и Баренцева морей, включающую современные Архангельскую, Вологодскую, Мурманскую области, север Ленинградской области, а также Республику Карелия и Республику Коми. Западную и восточную границы составляют контактные зоны русских с карелами и коми народами. Культура этих этносов, развивавшаяся под сильным севернорусским влиянием, сохранила национальную специфику, как отчасти сохранили ее и расселенные среди русских небольшие группы вепсов, ижоры и води. Ярко выраженную этническую специфику имеют на востоке Русского Севера пермские народы: коми-зыряне, пермяки и удмурты. Это объясняется как более поздним вступлением в контакты с северорусским населением, так и особенностями социально-экономического развития. Этот район можно считать контактной восточной зоной Русского Севера. Наиболее размытая граница южная. Этим объясняются плавность, размытость перехода севернорусской зоны в среднерусскую.

Понятие «Архангельский Север», которое ввел А. А. Куратов, в историко-культурном пространстве осмысляется в том контексте, что его территория составляла ядро Русского Севера и его этнокультурной традиции. Архангельский Север входил в состав более крупных регионов или дробился на части, но всегда соотносился с такими ареалами, как Заволочье, летописная «Заволочская Чудь» (XI - XIV в.), Двинская земля (XIV - XVII в.), Архангелогородская губерния (с 1708 г.), Архангельская область в составе Вологодского наместничества (с 1780 г.), Архангельское наместничество (c 1784 г.), Архангельская губерния (1796 1929 гг.), Северный край (1929 - 1936 гг.), Северная область (1918 - 1920 гг.; 1936 - 1937 гг.), Архангельская область в составе РСФСР и РФ. 
Таким образом, исторически правильнее говорить не об Архангельской области, а об Архангельском Севере [5, С. 3 - 4].

Самый многочисленный из народов Севера - русские. Исторический процесс их формирования на этой территории охватывает время с XII по XVII в. Первые славянские поселенцы, выходцы из Новгорода Великого, Ладоги, а позднее из Твери, Ростова Великого, Москвы, появились здесь в XI - XII в. Большую роль в народной колонизации сыграли северные реки: Онега, Северная Двина, Мезень, Вага, Пинега, Печора. Северное население впитало в себя традиции славянской культуры, а также аборигенов - финно-угров. Поскольку освоение и заселение Севера происходило в форме народной колонизации, заложившей уже на начальных этапах мирные отношения с коренным дорусским населением края, здесь никогда не случалось межэтнических конфликтов. Такой феномен - мирное сосуществование народов характерен и для настоящего времени.

Образ Русского Севера сыграл выдающуюся роль в становлении национального самосознания. Одним из первых, кто использовал топоним Русский Север, был архангельский губернатор А. П. Энгельгардт. По результатам двухлетнего путешествия по вверенной губернии в 1896 г. он издает книгу «Русский Север. Путевые заметки». В тексте книги А.П. Энгельгардт использует нетопонимическую форму словосочетания русский Север (русский с маленькой буквы), но уже в ее заголовке оно приобретает форму топонима. Среди первых исследователей, использовавших нетопонимическую форму (русский Север), был известный историк и правовед М. М. Богословский. Его фундаментальный двухтомник «Земское самоуправление на Русском Севере в XVII веке» был опубликован в 1909 и 1912 гг. [2, с. 57].

Географическое название русский Север, введенное в научный и общественный оборот, превратилось в макрорегиональный топоним, который воспринимается как естественный за ним стоит мощный культурно-ландшафтный регион Русский Север. Его естественность заключается в том, что Русский Север несет на себе функцию географического названия метки (север России) и топонимическую функцию за счет использования этнического прилагательного «русский». В научной литературе данный термин начинает широко употребляться со второй половины XIX в., и приходит на смену ранее широко бытовавшим понятиям «север России», «Поморье», «Поморский край» [7, С.179]. Эта замена термина усложнила и внесла некоторые противоречия в представление о составе населения, характере культуры обширной территории. В первую очередь противоречивость и дискуссионность понятия «Русский Север» отразилась в том, что обширная территория, издавна заселенная карелами, коми-зырянами, комипермяками, ненцами, саамами и русскими, оказалась названной именем одного народа. Структура понятия «Русский Север» как определенной территории и историко-культурной общности сформировалась в результате русской колонизации и ассимиляции коренного населения [8, С. 181].

Русский Север являлся контактной зоной разных этнических культур, но особые условия русской колонизации и исторического развития превратили его в заповедник древнерусской культуры. Одним из главных научных аргументов длительной устойчивости подобных представлений является фактор национального самосознания, ибо Русский Север сыграл выдающуюся роль в создании общерусских культурных символов, а их творцы стали олицетворением лучших черт национального духа и характера: свободолюбивые новгородские ушкуйники, былинные певцы, староверы - ревнители «истинного благочестия», гениальные зодчие и иконописцы, монахи - основатели монастырей, мужественные мореплаватели и землепроходцы. В этом отношении феномен Русского Севера имеет для России огромное значение, поскольку очевидно, что в его культуре сконцентрировались в семиотические образы вековые духовно-моральные и социокультурные искания русского народа [4, С. 4].

Особенность северной русской культуры состоит в том, что она сформировалась в экстремальных географических и климатических условиях и по сей день является границей ойкумены - «пространства обитания человечества». Это «модель северной культуры», которая была создана на пределе выживания этноса, когда актуальным становится вопрос о ее существовании. Она формировалась и функционировала в специфическом этническом и культурном окружении, вот почему севернорусская культурная традиция была крайне продуктивной и творческой. В подобной «рубежной» ситуации культура мобилизует все свои внутренние ресурсы, когда включаются механизмы самосохранения, связанные с обеспечением ее целостности. В борьбе за выжи- 
ваемость отбрасываются многие несущественные черты и резко повышаются ее стремление к сохранению культурной идентичности, рефлективность, интровертность [9, С.144-145]. Культура обращается к своим исходным основаниям, возрастает роль ее самосознания, духовности, которые служат опорой для ее самосохранения. Если в других землях русского государства происходило затухание, омертвление архаических традиций, то перенесенная на Север модель русской культуры порождала все новые и новые «тексты» культуры, которые были подобны древнерусским образцам. Теория «вторичной архаики» северной русской культуры была разработана в начале 70-е гг. XX в. В частности, на основе анализа исторического возраста севернорусской архаики был сделан вывод о том, что большинство явлений, общих для всей севернорусской зоны (типы жилища, традиционный костюм, общий характер обрядности, «эпический» характер фольклорной традиции, диалекты), восходит не к древнерусским племенным отношениям и даже не к древнерусским локальным традициям, а формировались позднее (как правило, в XIV-XV в.) и были исторически вторичны [10, С. 8]. Генезис севернорусской архаики был связан с регенерацией архаических форм культуры, которая происходила в условиях освоения русским народом северных земель, втягивавшихся в орбиту российской государственности. Процесс регенерации архаики проявлялся, в частности, в возврате к «золотому веку», к идеализированным общинным архаическим формам хозяйственного, социального, религиозного быта [11]. Концепция К. В. Чистова о вторичности севернорусской культурной традиции, ее огромном творческом потенциале получила дальнейшее развитие в трудах, посвященных культуре русских поморов $[12,13,14]$.

Моделирующие функции северорусской народной культуры проявились в восприятии Русского Севера как «светлого», т. е. святого. На Севере образовалась целая монашеская область - Северная Фиваида, которую православный писатель А. Н. Муравьев в 1855 г. назвал «Русской Фиваидой» по аналогии с Фиваидой Египетской, колыбелью раннехристианского монашества. Ученики и сподвижники Сергия Радонежского и Кирилла Белозерского стояли во главе монастырской сакрализации северных земель. «Преподобный Сергий стоит во главе всех, на южном краю сей чудной области и посылает внутрь ее сво- их учеников и собеседников, а преподобный Кирилл на другом ее краю приемлет новых пришельцев и расселяет обители окрест себя, закидывая свои пустынные мрежи даже до Белого моря и на острова Соловецкие» [15, С. 7-8, 33]. «Огромное число новых монастырей возникло среди лесов... волжско-двинского водораздела, который стал северной Фиваидой православного Востока» [16, С. 102-103]. B XIV-XV веках здесь были основаны такие значительные монастыри, как Кирилло-Белозерский, Ферапонтов, Соловецкий, АнтониевСийский, Артемиево-Веркольский, Александро-Ошевенский, Михайло-Архангельский. К началу XVII века их количество достигло нескольких десятков. Многие северные подвижники, прославившиеся своими духовными подвигами и как основатели монастырей, были канонизированы Русской Православной Церковью и причислены к лику святых.

Писатель Борис Шергин отмечал черты «традиционализма» северного крестьянина в его эстетических вкусах и пристрастиях. «Приобретая или заказывая новую икону, требовали, чтобы пошиб был «священный», канонический. «Живописную» манеру иконописания северный народ считал снижением, профанацией» [17]. При строительстве деревянных храмов Русского Севера указывалась на то, что архитектурный облик новой церкви должен соответствовать традиции и старым образцам, культовые постройки возводились «по подобию», что зафиксировано в порядных документах.

B XVII в. завершается процесс формирования севернорусской этнографической общности, ее социально-хозяйственных и культурно-этнологических признаков. Европейский Север приобретает признаки единой хозяйственно-культурной макротерритории, на которой развилось пашенное земледелие. В регионе было распространено прибрежноречное, прибрежно-приозерное и приморское гнездовое (оазисное) расселение, тесно связанное с природным ландшафтом и отличающееся невысокой плотностью населения. Социально-правовой доминантой было преобладание черносошно-государственного крестьянства и соответствующих механизмов управления, свойственного системе «государственного феодализма» [19, С. 233].

Среди северноруссов выделяется также этнографическая группа (субэтнос) поморы - русское население, проживающего на берегах Белого и Баренцева морей. Помо- 
ры выработали бесценный опыт выживания и хозяйственной деятельности в экстремальных условиях Крайнего Севера. В течение XIX в. сложилось представление о поморе как об особом типе русского человека, обладающем особыми чертами характера - предприимчивостью, смелостью, умом, независимостью в делах и суждениях. Писатель Федор Абрамов охарактеризовал поморов как людей великого мужества, выносливости, терпения, предприимчивых, «быстродумных», «государственников» по духу своему и складу мышления. Ведь именно они, поморы, первыми прорубили окно в Европу. Отсюда, из Поморья, началось то грандиозное движение русского народа в Сибирь, на Восток, которое известно под завораживающим названием «встречь Солнцу» [20, С.30 - 32].

Отважные северные мореплаватели освоили морской путь на новую землю, в Сибирь и на запад - Шпицберген. Континентальный менталитет, свойственный славянам сменился на Севере более открытым и активным мировосприятием морских народов. В поморской среде бытовала поговорка: «Apхангельский город всему морю ворот». Крестьяне-земледельцы, пришедшие на Север из новгородских и ростово-суздальских земель, сделали своим «полем» море, где добывали рыбу, морского зверя, создали своеобразную морскую культуру. На деревянных судах, приспособленных для арктических плаваний, достигали островов Новой Земли и Шпицбергена. Велика роль в освоении Арктики наших соседей - норвежцев, здесь на Севере Европы появился уникальный опыт сотрудничества двух культур, которые обогащали друг друга.

Русские поморы и норвежцы имели свой язык «руссенорскк» или «Моя-по-твоя» - смешанный русско-норвежский язык (один из примеров пиджина), обслуживавший общение поморских и норвежских торговцев на северном побережье Норвегии. Он существовал с 1750 - 1920-е гг., когда велась активная морская торговля зерном и рыбой между Норвегией и российским Поморьем. В руссенорске зафиксировано около 400 слов, 50 \% лексики - из норвежского языка, 40 \% - из русского, остальные заимствованы из английского, нидерландского, нижненемецкого, финского и саамского. Грамматика и фонетика чрезвычайно упрощены. Руссенорск имеет одну интересную особенность, которая свидетельствует, что русские и норвежцы были социально равноправными партнерами. Весь- ма во многих пиджинах в различных частях света один из языков играл доминирующую роль, в случае с руссенорском, напротив, количество русских и норвежских слов одинаково. B XVII-XVIII в. Русский Север имел самый высокий показатель грамотных сельских жителей не только в России, но и в Европе.

Этот край внес значительный вклад в развитие Российского флота, стал колыбелью отечественного судостроения. В 1693 г. при личном участии Петра Великого заложен, а в 1694 г. на Соломбальских островах построен и спущен на воду первый русский торговый корабль «Святой Павел».

Русский Север - родина первых российских землепроходцев: Е. Хабарова, С. Дежнева, А. Баранова. В честь Архангельска столица Русской Америки - Ситха - была названа Ново-Архангельском. Здесь родина многих выдающихся ученых, среди которых первым надлежит назвать М. В. Ломоносова, первого русского академика, основателя Московского университета. М. В. Ломоносов - выходец из поморской среды, он вырос в поморской семье в д. Куростров.

Специфика жизни человека в условиях Севера формировала особый тип мышления и менталитета, опорой которому было православие. Особенностью северного менталитета является то, что в нем заложен генетический код севернорусской культуры. Посредством культурной традиции он передается из поколения в поколение. «Русский Север! Мне трудно выразить словами мое восхищение, мое преклонение перед этим краем. Когда впервые мальчиком тринадцати лет я проехал по Баренцеву и Белому морям, по Северной Двине, побывал у поморов, в крестьянских избах, послушал песен и сказок, посмотрел на этих необыкновенно красивых людей, державшихся просто и с достоинством, я был совершенно ошеломлен. Мне показалось только так и можно жить по-настоящему: размеренно и легко трудясь и получая от этого труда столько удовлетворения. В каком крепко слаженном карбасе мне довелось плыть, каким волшебным мне показалось рыболовство, охота! А какой необыкновенный язык, песни, рассказы... Я зачарован им до конца моих дней. В Русском Севере удивительнейшее сочетание настоящего и прошлого, современности и истории, человека и природы, акварельной лиричности воды, земли, неба, грозной силы камня, бурь, холода, снега и воздуха» [18, с. $409-410]$. 
Важным фактором, определившим своеобразие Русского Севера, было отсутствие крепостного права в его законченной форме. Крестьяне Севера были «государственными», они платили многочисленные подати, несли казенные повинности, но наиболее тяжелой формы крепостничества - барщины и личной зависимости - здесь не было. Никогда не угасал на Русском Севере дух вольнолюбия и предприимчивости. Кроме государственных, «черносошных» крестьян (название произошло от словосочетания «черные сохи», т. е тяглые, зависимые от государства земли.) Вторая форма землевладения - дворцовая была также распространена на Севере; дворцовые земли принадлежали московскому князю, царю, императорскому «уделу» (отсюда - удельные крестьяне). Довольно рано (c XII в.) начала складываться третья форма землевладения - монастырско-церковная [21, C. 13]. «Архангельский мужик стал велик и разумен не по своей и божьей воле. Ему чрезвычайно помогло то обстоятельство, что он был именно архангельским мужиком-поморцем, никогда не носившим крепостного ошейника» [22]. Все это позволяет утверждать, что жители Русского Севера были, скорее, своего рода гражданами мира, чем подневольными подданными Российской империи[2].

Как известно, татаро-монгольское нашествие, захлестнувшее почти всю Русь, миновало Север. Здесь не затухал огонь русской государственности и национальной культуры. Когда преемственность исконных традиций русской культуры, восходящих к Киевской Руси, если не прервалась, то нарушилась, на Севере эта культура и ее традиции сохранялись в своей чистоте.

Вторая половина XVII в. отмечена в истории русского государства событием незаурядным: имя ему - раскол. В это время на Север со всех концов России бежали от церковной реформы патриарха Никона тысячи старообрядцев. Здесь возникали скиты и поселения староверов, их оплотом на Севере стала Выговская обитель, знаменитая своими традициями и изготовлением мелкой пластики медных литых икон, крестов, украшенных разноцветными эмалями. Северные земли, куда не всегда доходили официальные царские и церковные указы, в течение более двух веков были главной цитаделью раскола.

Заслуживает внимания тот факт, что в традиционной культуре Русского Севера сказалось влияние средневековой русской и евро- пейской городской культуры, а также в целом влияние Западной Европы: Англии, Голландии, Германии. Норвегии. В XVI - XVII в. в торговлю через Архангельск было задействовано более 70 русских городов, а торговый оборот русских и иностранных товаров был одним из самых больших в Европе. Важнейшую роль в социокультурном развитии края сыграли северные города: Каргополь, Сольвычегодск, Холмогоры, Архангельск, Вологда, Великий Устюг с их высоким уровнем ремесел, торговли, сложными общественными процессами. В 1775 г. по административной реформе Россия была разделена на 50 губерний, а города были разделены на три типа: 50 губернских, 493 уездных, 186 заштатных. В северных губерниях было достаточное количество торговых сел, которые без особого труда были переименованы в города. В 1780 г. по предложению архангельского генерал-губернатора А.П. Мельгунова уездными центрами стали города Мезень, возникший путем соединения двух слобод, Пинега и Онега, которые образовались от соединения нескольких сел. Например, население г. Пинега через 20 лет выглядело следующим образом: «Новые купцы и мещане начали принимать облик русских городских жителей и торговать мелочными товарами, но более еще держатся старых крестьянских привычек» [23, С. 107]. Вместе с тем некоторые населенные пункты, волею судеб не получившие или утратившие статус города, по образу жизни его обитателей в большей степени соответствовали городскому населению. Это посады Ненокса, Уна, Луда, в которых жители только называются посадскими, но на самом деле являются наемными работниками у архангельских купцов-солеваров. Это относится также и к крупным торговым селам на Северной Двине (Черевково).

В связи с историко-культурным изучением Русского Севера важно отметить исследование В.О. Ключевского о роли природы и ландшафта в истории России и в генезисе русской идеи. Жизнь славянина с древнейших времен была связана с водой. Излюбленным местом для возведения деревень был берег реки, здесь проходили главные торговые пути. Русская река приучала своих обитателей к общежитию и общительности, воспитывала дух предприимчивости и привычку к совместному артельному труду, кормила и поила, сближала разбросанные части населения, приучала чувствовать себя членом общества, общаться с чужими людьми, наблюдать их нравы и обычаи, 
меняться товаром и опытом. Русский человек «на реке оживал и жил с ней душа в душу» [24, C. 85]. Северные деревни, расположенные на берегу реки или озера, в открытом поле или на высокой горе, у воды или у леса всегда господствовали над местностью, становились центром окружающего ландшафта. Особенности культуры Русского Севера - это результат яркого проявления в ней русского хронотопа - смыслового единства времени и пространства, слияние в некое единое целое социокультурной среды и географической обстановки. Древнерусская культура строилась на идее главенства внеличностного начала, коллективности, всеобщности процессов культурного творчества, его анонимности. В качестве предметного воплощения гармонии времени и пространства, согласно нашим исследованиям, выступает культурный ландшафт северной деревни, «являющий собой хороводную, соборную картину мира» [25, С. 152].
Особая роль Русского Севера в истории русской культуры связана с тем, что он стал своего рода хранителем ее генофонда. В силу маргинального положения Русского Севера в конце XVIII - начале XIX в. произошла своеобразная “консервация" русской культуры, в то время как в других регионах России, она претерпевала существенные изменения. Таким образом, до начала XX века сохранились образцы древнерусского зодчества, былинные и песенные традиции, древнерусская книжная культура, иконописание. И своеобразное научное и художественное открытие его в XIX - начале XX в. дало толчок к пониманию Русского Севера как особого русского пространства, где сохранились истоки национальной самобытности, где культура несет некий генетический код, который посредством традиции передувается из поколения в поколение $[1,2,3]$.

\section{Библиография:}

1. Пермиловская А.Б. Русский Север как особая территория наследия. Архангельск: Правда Севера; Екатеринбург: УрО РАН, 2010. 552 с.

2. Пермиловская А.Б. Культурные смыслы народной архитектуры Русского Севера. Екатеринбург: УрО РАН, Архангельск : Правда Севера; Ярославль : ЯГПУ, 2013. 608 с.

3. Е.Ф. Фурсова, А.Б. Пермиловская, А.В. Черных и др. Сибирь и Русский Север: проблемы миграций и этнокультурных взаимодействий (XIX - начало XXI века): колл. науч. моногр. Новосибирск: Изд-во Института археологии и этнографии СО РАН, 2014. 296 с.

4. Русский Север: ареалы и культурные традиции. СПб.: Наука, 1992. 272 с.

5. Куратов А.А. История и историки Архангельского Севера. Архангельск: Изд-во Помор. гос. ун-та, 1999. 271 с.

6. Русский Север. Этническая история и народная культура XII-XX века. М: Наука, 2001. 848 с.

7. Калуцков В.Н. Ландшафт в культурной географии. М.: Новый хронограф, 2008. 320 с.

8. Соловьева А.Н. Этничность и культура: проблемы дискурс-анализа. Архангельск: Кира, 2009. 231 с.

9. Теребихин Н.М Сакральная география Русского Севера. Архангельск: Изд-во Помор. межд. пед. ун-та, 1993. $223 \mathrm{c}$.

10. Чистов К.В. Проблемы этнографического и фольклорного изучения Северо-Запада СССР // Этнографические исследования Северо-Запада СССР: традиции и культура сельского поселения. Этнография Петербурга. Л., 1977. С. 5-10.

11. Чистов К.В. Народные традиции и фольклор. Л.: Наука, 1986. 304 с.

12. Бернштам Т.А. Поморы. Л.: Наука, 1978. 176 с.

13. Бернштам T.А. Русская народная культура Поморья в XIX - начале XX в. Л.: Наука, 1983. 233 с.

14. Базарова Э.Л., Бицадзе Н.В. и др. Культура русских поморов. М.: Научный мир, 2005. 400 с.

15. Муравьев А.Н. Русская Фиваида на Севере. СПб.: в типог. ІІІ Отд. Собственной Е.И. В. Канцелярии, 1855. $503 \mathrm{c}$.

16. Ключевский В.О. Афоризмы. Исторические портреты и этюды. Дневники. М.: Мысль, 1993. -415 с.

17. Шергин Б.В. Поэтическая память. М.: Сов. Россия, 1978. 128 с. Цит. по: Соловьева А.Н. Указ. соч. С. 180.

18. Лихачев Д.С. Русская культура. М.: Искусство, 2000. 440 с.

19. Камкин А.В. Союзы севернорусских крестьянских миров в системе расселения и жизненной повседневности XVII - XVIII вв. // Мировоззрение и культура севернорусского населения. М.: Наука, 2006. С. 233 - 243.

20. Абрамов Ф.А. Чем живем - кормимся. Л.: Сов. писатель, 1986. 527 с.

21. Поморская энциклопедия. Т. 1: История Архангельского Севера. Архангельск: ПГУ, 2001. 483 с. 
22. Отмечал Г.В. Плеханов, говоря о жизненном пути М.В. Ломоносова: Цит. по: Заповедный Север. Архитектура. Искусство. Ландшафт. М.,1987. С. 9.

23. Пошман А. Архангельская губерния в хозяйственном, коммерческом, философическом, историческом, топографическом, статистическом, физическом и нравственном обозрении, с полезными на все оные части замечаниями. СПб., 1866. Т. 1. 194 с.

24. Ключевский О.В. Курс русской истории. М.: Мысль, 1989. 399 с.

25. Чекалов А.К. Народная деревянная скульптура Русского Севера. М.: Искусство, 1974. 191 с.

26. Кузнецова Н.Ю. Старообрядчество Европейского Севера по материалам А. С. Пругавина: эволюция внутриконфессиональных границ // Исторический журнал: научные исследования. - 2015. - 2. - С. 215 - 227. DOI: $10.7256 / 2222-1972.2015 .2 .16092$.

27. Даниленко Д.В. Why Russians are so different? // SENTENTIA. European Journal of Humanities and Social Sciences. - 2015. - 4. - C. 1 - 35. DOI: 10.7256/1339-3057.2015.4.17642. URL: http://www.e-notabene.ru/ psen/article_17642.html

28. Лебедев С.В., Максимович В.Ф. Русский Север: исторические и этнокультурные особенности формирования российского региона // Человек и культура. - 2015. - 6. - С. 28 - 63. DOI: 10.7256/24098744.2015.6.15788. URL: http://www.e-notabene.ru/ca/article_15788.html

29. Немаева Н.О. Формирование российской социальной и культурной идентичности посредством возрождения сакрального искусства // Социодинамика.-2015.-2.-C. 54-67. DOI: 10.7256/2409-7144.2015.2.14404. URL: http://www.e-notabene.ru/pr/article_14404.html

\section{References (transliterated):}

1. Permilovskaya A.B. Russkii Sever kak osobaya territoriya naslediya. Arkhangel'sk: Pravda Severa; Ekaterinburg: UrO RAN, 2010. $552 \mathrm{~s}$.

2. Permilovskaya A.B. Kul'turnye smysly narodnoi arkhitektury Russkogo Severa. Ekaterinburg: UrO RAN, Arkhangel'sk : Pravda Severa; Yaroslavl' : YaGPU, 2013. 608 s.

3. E.F. Fursova, A.B. Permilovskaya, A.V. Chernykh i dr. Sibir' i Russkii Sever: problemy migratsii i etnokul'turnykh vzaimodeistvii (XIX - nachalo XXI veka): koll. nauch. monogr. Novosibirsk: Izd-vo Instituta arkheologii i etnografii SO RAN, 2014. $296 \mathrm{~s}$.

4. Kuratov A.A. Istoriya i istoriki Arkhangel'skogo Severa. Arkhangel'sk: Izd-vo Pomor. gos. un-ta, 1999. 271 s.

5. Kalutskov V.N. Landshaft v kul'turnoi geografii. M.: Novyi khronograf, 2008. $320 \mathrm{s.}$

6. Solov'eva A.N. Etnichnost' i kul'tura: problemy diskurs-analiza. Arkhangel'sk: Kira, 2009. $231 \mathrm{~s}$.

7. Terebikhin N.M Sakral'naya geografiya Russkogo Severa. Arkhangel'sk: Izd-vo Pomor. mezhd. ped. un-ta, 1993. $223 \mathrm{~s}$.

8. Chistov K.V. Problemy etnograficheskogo i fol'klornogo izucheniya Severo-Zapada SSSR // Etnograficheskie issledovaniya Severo-Zapada SSSR: traditsii i kul'tura sel'skogo poseleniya. Etnografiya Peterburga. L., 1977. S. 5-10.

9. Chistov K.V. Narodnye traditsii i fol'klor. L.: Nauka, 1986. 304 s.

10. Bernshtam T.A. Pomory. L.: Nauka, 1978. 176 s.

11. Bernshtam T.A. Russkaya narodnaya kul'tura Pomor'ya v XIX - nachale XX v. L.: Nauka, 1983. 233 s.

12. Bazarova E.L., Bitsadze N.V. i dr. Kul'tura russkikh pomorov. M.: Nauchnyi mir, 2005. $400 \mathrm{~s}$.

13. Murav'ev A.N. Russkaya Fivaida na Severe. SPb.: v tipog. III Otd. Sobstvennoi E.I. V. Kantselyarii, 1855.503 s.

14. Klyuchevskii V.O. Aforizmy. Istoricheskie portrety i etyudy. Dnevniki. M.: Mysl', 1993. - 415 s.

15. Shergin B.V. Poeticheskaya pamyat'. M.: Sov. Rossiya, 1978. 128 s. Tsit. po: Solov'eva A.N. Ukaz. soch. S. 180.

16. Likhachev D.S. Russkaya kul'tura. M.: Iskusstvo, 2000. $440 \mathrm{~s}$.

17. Kamkin A.V. Soyuzy severnorusskikh krest'yanskikh mirov v sisteme rasseleniya i zhiznennoi povsednevnosti XVII - XVIII vv. // Mirovozzrenie i kul'tura severnorusskogo naseleniya. M.: Nauka, 2006. S. 233 - 243.

18. Abramov F.A. Chem zhivem - kormimsya. L.: Sov. pisatel', 1986. 527 s.

19. Otmechal G.V. Plekhanov, govorya o zhiznennom puti M.V. Lomonosova: Tsit. po: Zapovednyi Sever. Arkhitektura. Iskusstvo. Landshaft. M.,1987. S. 9.

20. Poshman A. Arkhangel'skaya guberniya v khozyaistvennom, kommercheskom, filosoficheskom, istoricheskom, topograficheskom, statisticheskom, fizicheskom i nravstvennom obozrenii, s poleznymi na vse onye chasti zamechaniyami. SPb., 1866. T. 1. $194 \mathrm{s.}$

21. Klyuchevskii O.V. Kurs russkoi istorii. M.: Mysl’, 1989. 399 s. 
22. Chekalov A.K. Narodnaya derevyannaya skul'ptura Russkogo Severa. M.: Iskusstvo, 1974. 191 s.

23. Kuznetsova N.Yu. Staroobryadchestvo Evropeiskogo Severa po materialam A. S. Prugavina: evolyutsiya vnutrikonfessional'nykh granits // Istoricheskii zhurnal: nauchnye issledovaniya. - 2015. - 2. - C. 215 - 227. DOI: 10.7256/2222-1972.2015.2.16092.

24. Danilenko D.V. Why Russians are so different? // SENTENTIA. European Journal of Humanities and Social Sciences. - 2015. - 4. - C. 1 - 35. DOI: 10.7256/1339-3057.2015.4.17642. URL: http://www.e-notabene.ru/psen/ article_17642.html

25. Lebedev S.V., Maksimovich V.F. Russkii Sever: istoricheskie i etnokul'turnye osobennosti formirovaniya rossiiskogo regiona // Chelovek i kul'tura. - 2015. - 6. - C. 28 - 63. DOI: 10.7256/2409-8744.2015.6.15788. URL: http://www.e-notabene.ru/ca/article_15788.html

26. Nemaeva N.O. Formirovanie rossiiskoi sotsial'noi i kul'turnoi identichnosti posredstvom vozrozhdeniya sakral'nogo iskusstva // Sotsiodinamika. - 2015. - 2. - C. 54 - 67. DOI: 10.7256/2409-7144.2015.2.14404. URL: http://www.e-notabene.ru/pr/article_14404.html 